Kohl: a Journal for Body and Gender Research

Vol. 5, No. 1 (Spring 2019)

\title{
Arts-Informed Inquiry: Possibilities and Potential for Decolonising Methodology
}

\author{
Shama Dossa
}

\begin{abstract}
:
This paper explores the potential and contextual difficulties of experimenting with arts-informed research as a methodology through a decolonizing transnational feminist lens in the context of Pakistan. The approach was applied as part of a study with community development workers to explore the theory and practice or praxis of empowerment in development discourse. Although challenging, I believe that the approach has the potential to make research more relevant, accessible, and community-centered, honouring diverse ways of knowing. It can facilitate critical collaborative meaning-making in every day contexts, which is important for community development, women's movements, and feminist theorizing.
\end{abstract}


As a feminist researcher and community development practitioner, I believe that knowledge production must be a collaborative process situated in the everyday. It requires:

knowing that relations of power are inherent in all forms of collaboration yet hoping too that political alliances can be created in spaces where people can come together despite their differences to think, listen, contemplate and act (Ahmed, 2017, p. 3).

Drawing on arts-informed research as a methodology, my study focuses on the theory and practice of empowerment in community development in the context of Karachi, Pakistan. Emerging from a feminist critique of mainstream neoliberal development policy, empowerment discourses "have given rise to some unlikely advocates... including the World Bank" (Kabeer, 2001, p. 17). Although feminist academics/activists have been critical of imperialist, neo-liberal, and politico-religious co-optations of empowerment frameworks (Cornwall \& Brock, 2005; Kabeer, 2001; Parpart, Connelly, \& Barrteau, 2000; Rowlands, 1998; Zia, 2018), few have talked about the regulatory and disciplining potential of their application and praxis (Nagar, 2006; Sharma, 2008). The postcolonial modernizing discourse tends to pre-identify, pre-construct, and categorize community development workers/mobilizers as empowered bodies, catalysts, and change agents. These bodies are expected and assumed to facilitate a transformation in "oppressed" peoples' self-image and beliefs about their rights and capabilities. This assumption is problematic given that many development workers are themselves in positions of precarious employment, with short-term contracts, and few benefits (Nagar, 2006; Sharma, 2008). Limited attention seems to also have been paid to the material effects of empowerment narratives on the lives of the workers who are meant to carry out the "work" of empowerment. Provided with guidelines based on project objectives and lists of targets, many development workers/mobilizers in Pakistan tend to live with expectations of how best to "translate/transform" empowerment from the abstract into the concrete, while restricted in their space to critically reflect on theoretical notions that drive their practice. My study provides insight into the economy of empowerment narratives and the potential they have to mediate "encounters," shaping "subject" and "other." I do so by critically exploring how bodies of community development workers are put and made to work. Located in the urban metropolis of Karachi, these community workers/mobilizers are embedded in a web of multiple intersecting structures of oppression and power relations. Drawing on feminist poststructuralist and postcolonial theory, my work explores how these workers "encounter," theorize, strategize, and act upon understandings of empowerment and community development through an arts-informed cooperative inquiry. Such an analysis requires introspection - turning the gaze inward and reflecting on the discursive and material outcomes of empowerment work and power relations. Ahmed (2000) terms this "ethical encounters," or "ethical representations and readings" (p. 140) of narratives through a self-reflexive reworking of the "terms" under which they take place.

This paper explores the methodological and contextual potential for feminist theorizing through arts-informed research with community development workers, shifting the power relations inherent in research and development discourse. As such, the focus of this paper is not on the findings of my study; rather, it specifically reflects on the methodological journey. I first lay out the context of social science research in Pakistan, then describe the approach as well as its application and utility for feminist praxis. I argue that this 
approach can be used for individual and collective analysis and insight into the economy of empowerment narratives. Not only does this approach challenge colonial conceptions of research, but it also allows me to ask important questions such as: how do we create relationships with others that are more just? How can we support those whose voices are marginalized without taking over their struggle? And how do we dismantle the histories we "keep coming up against" and "that have ... become as solid as walls?" (Ahmed, 2017, p. 1).

\section{Decolonising Methodology: Feminist, Artful, and Cooperative}

As scholar-artist, I research and write in order to understand, provoke, and promote action. I tend to think in colours; my ideas spread out, visual, animated, multidimensional, tangible, emotions linked with sound, smell, taste, touch, and sight. Coming towards scholartistry and arts-informed research has been a long but serendipitous process of personal reflection and risk taking. As a scholar and artist, I now draw on a mode/form of qualitative research where the arts serve as a framework for research inspiration, conceptualization, process, and representation in the social sciences (Cole \& Knowles, 2008). It allows me to work with conventional qualitative research methods such as in-depth interviews, and multiple forms of creative expression such as fiction, poetry, reader's theatre, and photovoice, amongst many others. I wanted to engage in a creative process of collaborative meaning-making and expression with research participants through interactive art-making workshops to trouble conventional empowerment narratives.

This mode of inquiry links my poststructuralist sensibilities with my connection to the arts, and the way I understand the world. Yet, it conflicts with the context-specific colonial discourses of research and relations of power my participants and I encounter within academia in South Asia, where such ways of knowing and representation are not regarded as "legitimate research." My experience of graduate teaching and research in Pakistan with universities, NGOs, and international donors over the last fifteen years has been challenging. The political economy of research is suffocating for scholartists who, like myself, are engaged in critical pedagogical work. Colonizing and civilizing discourses are still a central part of knowledge construction and research work in the worlds I inhabit.

In the context of academia, professional degrees in medicine, engineering, and more recently business administration and computer science still hold primary importance. Neither are graduate degrees in social work, sociology, anthropology, and women's studies considered of significant value, nor is feminist research. The general sentiment is that the social sciences are the last option for students, and tend to pay the lowest, reflecting the hierarchy (Pervaiz, 2003).

In the context of community development, it is impossible to conduct research through local funding due to the lack of resources and priority given to the field. The state does provide some grants, but only conventional research is usually funded. Space for indigenous scholarly debate is dominated to a large extent by donor interests. NGOs are key service providers in this economy of research. Based on simple surveys and case studies, most tend to yield superficial information that generally lacks depth (Saigol, 2005). In my experience, this kind of knowledge generation is more focused on donor specifications for monitoring and evaluation. This 
discourages thorough painstaking feminist analysis and deconstructive thought, frustrating the few critical academics and activists struggling to change the system. However, there are exceptions where activist and academic collaborations do take place supported by donor funds and NGOs. These collaborations have to contend with scrutiny from an anti-state securitization and surveillance lens, as is the case with all research that is granted foreign funding from donors. In the past three years, further restrictions have been imposed: any organization that receives funding from outside the country now has to get multiple no objection certificates (NOCs) in order to operate. Seventeen INGOs were shut down by the federal government citing "security concerns" in 2018 and forty five have now been identified for closure on similar grounds (Sayeed, 2018; Rana, 2019) This has led to further precariousness of employment in the development sector and facilitated heightened surveillance by the state.

Sameshima (2008) writes that "art dynamically informs in its creation and again informs in its completion" ( $p$. 155). Arts-informed research requires a commitment to a particular art form that must be reflected in the research process and text, serving as a framework to define all aspects of the study (Cole \& Knowles, 2008). The focus is on the relationship between form and substance, responsiveness to the natural flow of events, serendipity, subjective and reflexive presence of the researcher, and audience engagement (lbid.). According to Cole (2002), arts-informed research appears as a response to traditional notions of research in academic systems that form barriers to representation and communication with the public at large. There is a need for alternative approaches that capture the complexities of the human experience, or what she terms "epistemological equity" - approaches that do not privilege the intellectual over the emotional and other sensory forms of knowing. The methods and form of research used must complement the inquiry, just as the representation must honour the research and provoke the audience. As McIntyre (2004) puts it, "research is needed to show that it makes sense to make sense with the senses" (p. 260). Through her work, the researcher needs to embody those principles and strive towards evoking and promoting emotion, thought, and action (Sameshima, 2008).

Artists in Pakistan tend to be disregarded as professionals, and the shadow of Islamization under the regime of military dictator Zia ul Haq remains. The 1980s saw a ban imposed on women performing, the introduction of veiling for women on television, pogroms led against artists and journalists, and the institutionalization of other misogynistic laws. Although Pakistan is now a constitutional democracy, the legacy of Islamization and its impact on women and other marginalized groups is ever present. In the case of the development industry, the arts have been used as a medium for advocacy, particularly with the messages shared via street theatre, telefilms or puppetry. However, the arts have not really been seen as a means of research, meaning-making, and representation of data. I believe that there is a need to shift the discourse, and my engagement with community workers and the arts shows this to be possible through arts-informed research.

\section{Data-Making and Representation}

According to Gannon and Davies (2007), 
poststructural work entails the politics of and practice of writing differently. It is through writing differently that thinking differently becomes possible. Neither comes prior to the other, but they are simultaneously realized through the folds and hinges of language. (p. 97)

Arts-informed research aims to shed light on the human condition (Gosse et al., 2008). It does so through scholartists creating open texts, challenging the audiences' expectations and assumptions in order to create "disequlibrium" (Gosse, Barone, \& Kaplan, 2008). Open texts admit the imagination of the reader as opposed to closed conclusive texts. Gosse et al. argue that works that are beautifully crafted can masquerade as art, and serve as propaganda. They exude certainty and serve to reinforce dominant paradigms (Gosse et al., 2008). According to Gosse et al. (2008), "There shouldn't be a solid theme or conclusion" (p. 69) in the representation. The objective is not to bring the audience closer to a singular "truth," but to see facets of it in a different light and envision how it may be otherwise (Gosse et al., 2008). To quote Dunlop (2008), "We read ourselves as we read" (p. 65). For audiences unused to this approach to research and representation, the notion of not having a concrete conclusion may be unsettling, while others may actively embrace it as an interactive mode of meaning-making.

Arts-informed research perceives the research text as co-creation between audience and researcher engaging the aesthetic. Readers should be conscious of the textual depictions as fabrications and how textualizing strategies shape research narratives. The reader actively constructs possible counterinterpretations and readings. Meaning, then, is also made in the subjective interaction of researcher and research participant or collaborator. Therefore, the fragments presented are "contemplative texts" accompanied by self-reflexivity and acknowledgment of my presence in the research.

My study uses a mixed genre of data-making and representation, defined by Richardson (2004) as a process where "the scholar draws freely in his or her productions from the literary, artistic, and scientific genres, often breaking the boundaries of each of those as well" (p. 483). I combine the genres of prose, performative writing, and short stories with more formal academic writing to complicate thought and highlight contradictions, workings of power, and cracks in empowerment narratives. This allows for "the subconscious (to be) made conscious through creative rendering" (Sameshima, 2008, p. 156) - for ideas to be thought and things to be said in ways that may otherwise not have been possible for me. I make data, write and analyze, analyze and write, make meaning and render; the process is integrated with the personal, the professional, the ethical, and the sensual.

The structure and form of representation of data and analysis in the study emerged from intimate engagement with data-making. Writing in this way allows me to connect the threads, moving through a process of clustering and thematically categorizing ideas, and experimenting with different forms of representation. As I wrote and rewrote, each piece, each fragment became part of a larger whole contributing to my argument. I also found Richardson's (2004) idea of "writing as a way of knowing" and as a method of discovery and analysis to be inspiring during this process. Based on my own experience, I concur that "by writing in different ways, we discover new aspects of our topic and our relationship to it. Form and content are hence 
inseparable" (p. 473). I also agree with Lorri Neilsen's (2002) claim that "knowing and knowledge are fictions as much as fiction is knowing and knowledge" (p. 208).

This approach freed me from trying to write a single text where "everything is said to everyone" (Richardson, 2004, p. 476). Writing has become a site for theorizing where the "telling and the told remain inseparable" (Minh-ha, 1989). There is no textual staging that is neutral or innocent, as "writing is always partial, local, and situational and that our Self is always present" (Richardson, 2004, p. 480). Hence, it is the interaction between self and the data that led me to experiment with a mixed genre of writings to complicate empowerment narratives.

Although I come to the arts from theatre, one of my joys in life is literary fiction, particularly postcolonial fiction and Urdu short stories. The fictional lens opens the door to complexities, colours of spaces, people, and the infinite possibilities of knowing the world. Somehow, this form of knowing and writing seems to draw me in completely. I have never had the same connection with conventional academic writing as I have had with fiction. Fluck (2003) argues that fiction has a stake in social justice precisely because it is responsible for carving out a space where other faces can be seen and other voices heard. The writing became an act of defiance and hope. I also feel that fictionalizing in research gives my work an ethical dimension. I feel I was able to get voices heard in a way that protected my participants from being identified and brought together threads of their stories in a way that was easier to share. According to Rishma Dunlop (2008), fiction:

becomes exploratory, explanatory, hopeful and generative ... fictional text constitutes the boundary crossings transgressing over referential fields of thought and textual systems of representation. ( $p$. 64)

Since I had no formal training in creative writing, I decided to attend creative writing workshops while I was in Karachi. The course was taught by a well-known Pakistani fiction writer, Kamyla Shamsi, and I indulged my lust for reading fiction while writing and experimenting with short stories, performative writing, and poetry, alongside more conventional academic writing, weaving them together as a means of representing data. I learned to work with images and metaphors. Sullivan (2009) writes:

So if we want a person to know what we feel, either in our own lives or empathically or imagined, we must know how to offer them the sensory experience that we have had or imagined. We have to transfer something from one body to another - this is what image and metaphor is all about ... tying the abstract to the concrete. (p. 113)

I understand the importance of making transparent the process of moving from data to the pieces produced in this text. Yet, the creative process of how the writer or poet moves from thoughts, images, and sensations to what is happening on the page at some level tends to remain impervious to articulation (Butler-Kisber, 2010 , p. 95). I would read transcripts of interviews and group discussions then listen to the audio recordings, identifying themes and storylines. 
For example, the context of Karachi emerged as a major theme for participants in our discussions. In particular, violence and experiences of violence surfaced in almost every interview. In an in-depth interview, Sakeena talked about the emotional and psychological toll of violence on herself and the people she works with:

Violence in the everyday changes people. They don't talk about the violence directly but they are less trusting, more high strung ... the constant frustration and fear of violence in the city ... within the household husbands beating wives, mothers beating children, people don't have patience anymore.

Ahmed talked about the political context of violence, particularly ethnic violence:

Political manipulation along ethnic line in Karachi coincides with loss of respect. It is also linked to military policy and the Afghan war, the post partition inheritance of ethnic disputes is exploited.

Nasir talked about how violence affected community mobilization work and how he feared for his family:

Issues are different from area to area in Karachi - water, electricity, gas, sanitation. You can mobilize people on these issues, these are safe ... it is harder when we talk about political violence, guns, and drugs. In my own neighbourhood there are young boys carrying guns. We have grown up with this fear I have lost friends ... Aap nahi kuch kar saktey yahan phir aap ka knowledge aur skills kisi khatey mey nahi ata (you can do nothing, then your knowledge and skills are useless)

It was these stories - my own notes from participant observation of living in the city along with archival research - that I fused together to represent findings from the study.

I found that creative writing and poetry gave me the liminal imaginative space to talk about and understand my data and writing in a way that almost became intuitive. The twists and turns in this liminal space were not controllable; they were intense and demanding, surprising, and very often confusing and disorientating. Yet, this way of writing and researching also became a place of possibility, openness, heightened awareness, and a place to let go (Neilson, 2002). In letting go, I also let go of the English language, replacing it with Urdu and Sindhi. The acts were conscious and risky. At times, I translated; in some cases, I chose not to. My choices to write in another language were political and epistemological, bringing the physical acknowledgement of alternative ways of knowing and grounding it physically in an English text. Other choices were serendipitous aesthetic where translation would take away from the flow and rhythm of writing.

Some transcripts provided poetic occasions that prompted me to fuse poetic and performative writing, repeating words over and over again. For example, participants used the word itefaqan (by chance) in many different contexts in interviews to talk about how they came into the profession. As I found it difficult to verbalise the nuances of meaning, I wrote a lyrical piece, one with a tempo, a rhythm, which I then found worked in the performative piece "Katha (A Story) in Four Acts." Excerpts: 


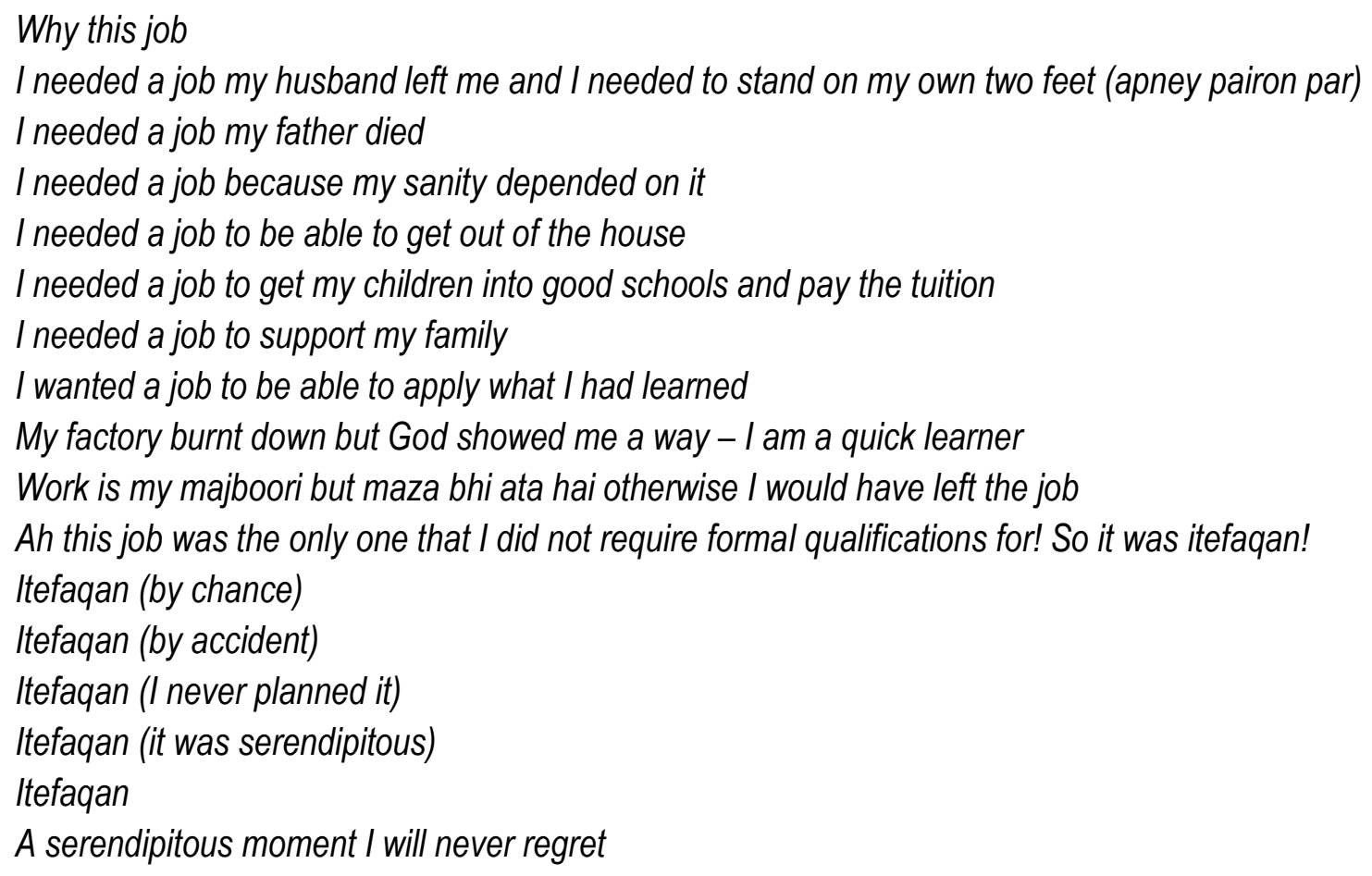

As a result, theory became implicit in writing. Yet, I was able to retain a complexity to both what was being said and how it was being said. My focus was neither on revelation, unveiling, and forcing of an agenda, nor was it prescriptive, telling people how to think. Instead, I presented disruptions of binaries: I found space for ruptures, leaving the text open to interpretation.

My representations of data and my analysis are aimed to be evocative, provocative, emotive, and sensual; the audience is invited to experience it bodily, emotionally, and intellectually. Reading and writing become acts of performance and resistance, in essence an intertwined act of performative inquiry (Dunlop, 2008). Through interacting with different literary and visual art forms, the expectation is for the audience to be moved by the artwork in some way, and that the audience is as responsible for the interpretation of the text as I am in its construction.

Thus, the impact of this genre of research relies on the meaning it evokes for each person who engages with it. The aim is not to communicate a single, intended message. There is no single "correct" interpretation; the representations are intentionally ambiguous - open texts.

My emphasis is on providing the audience with an open text as well as providing tools, maps, and guides to interpret the text, rather than telling them what meaning they should make out of it. What is most important to me is how that story is told. I acknowledge that this does not mean that everyone who reads the study will embark on some direct action which is transformative for them, but they may begin to think differently. My emphasis is on making research relevant and connecting academy with community through it. According to McIntyre (2004), 
As researchers we need to get people wanting to join in, needing to care. Revisioning the narrative

of research by placing dignity and respect as the guiding values in the relationship shifts the emphasis from objectivity and distance to a shared humanity of creativity in connection. (p. 260)

The complex, self-reflexive experiences and analysis of my participants and myself are constructed in a way that trespasses, troubles, challenges, and at times reinforces the borders and boundaries of existing assumptions around empowerment theory, practice, and subjecthood. Nothing was written in the order in which it was presented, nor were the experiences of my collaborators shared in a linear manner. Instead, it was a serendipitous process of inquiring as I engaged in conversations and wrote. I acknowledge the complicity of being part of weaving narratives. After all, these are stories about stories. The stories and artwork are based on our lives, as well as our individual and collective discussions around our work. I attempt to share the complexities and negotiations of our everyday and how we are engaged in a constant interactive performance where we switch roles, play multiple parts, strategize, and negotiate according to the circumstances we encounter.

There is a purpose in this narration, as it reflects who I am, how I know, how I see the world, and who I have come "to be" by staking claims and fashioning my subjectivity. I am in search of an approach that can do the same for others, or at least allows for the possibility for such re-encountering; an approach that acknowledges the flexibility of modes of being, of subject constitution; an approach that envisions or allows for the possibility of an ethic of re-encountering.

\section{Conclusion}

Feminist theory suggests that transformation will come through a process of empowerment, both individual and collective. There is a belief in solidarity, through modes of collaboration across borders. Yet, I no longer think this strategy to be as straightforward as it sounds. Through the use of the arts and interactive discussions, my collaborators and I began to complicate these narratives, creating open texts. Located within the context of everyday life in Karachi, the stories, artwork, performative writing, and prose emerged in relation to critical discussions on complicating empowerment. Placing the spotlight on narratives makes it possible for both the content of stories and the context of story-telling (social, cultural, and fantasy narratives) to be brought into focus, and emphasizes on the agency of narrators as well as the intended audience. The objective of such complication is to disrupt and denaturalize what is seen as natural, and interrupt essentialist thought. Analysis is focused on how certain modes of thought become possible and how empowerment narratives feed into and form dominant discourse - a regime of truth can itself be subjected to retracting and retelling (Kim, 2007, p. 83). However, this mode of analysis also requires sensitivity to the political complexities of engaging in critiques of empowerment talk and work, in cases where the NGO sector and private philanthropists provide the last resort to service delivery and support.

Through this approach, I learned how community workers/mobilizers, who can occupy multiple subject positions at any given moment, strategize and negotiate the power relations they are enmeshed in within the 
54 context of their work, at times by appropriating discursive space, contesting, and also reaffirming dominant narratives they encounter. As a result, empowerment narratives begin to appear to us as colliding discourses and multi-layered complex constructs; they may form unpredictable, messy, and contradictory assemblages (Sharma, 2008) as opposed to linear, universal, inevitable, and easily understood outcomes and processes. Although challenging, I believe that arts-informed research has the potential to make research more relevant, accessible and community-centered, honouring diverse ways of knowing. It can facilitate critical collaborative meaning-making in every day contexts, which is crucial for community development, women's movements, and feminist theorizing. 


\section{References}

Ahmed, S (2017). Living and Feminist Life. London: Duke University.

Ahmed, S. (2000). Strange encounters: Embodied others in post-coloniality. London: Routledge.

Batliwala, S. (2007). "Putting power back into empowerment" [Electronic Version]. openDemocracy. Retrieved September $\quad 30, \quad 2008, \quad$ from http://www.opendemocracy.net/article/putting_power_back_into_empowerment_0

Butler-Kisber, L. (2010). Qualitative inquiry: Thematic, narrative, and arts-informed perspectives. London: Sage.

Cole, A. (2002, November 12). "The art of research." University of Toronto Bulletin, p. 16.

Cole, A., \& Knowles, G. (2008). "Arts-informed Research." In A. Cole \& G. Knowles (Eds.), Handbook of the Arts in Qualitative Social Science Research: Perspectives, Methods and Issues (pp. 55-70). Thousand Oaks, CA: Sage.

Cornwall, A., \& Brock, K. (2005). "What do buzzwords do for development policy? A critical look at 'participation', 'empowerment' and 'poverty reduction'." Third World Quarterly, 26(7), 1043-1060.

Dunlop, R. (2008). "Boundary bay': Rishma Dunlop's story." In Four Arrows \& D. T. Jacobs (Eds.), The authentic dissertation: Alternative ways of knowing, research, and representation (pp. 61-65). New York: Routledge.

Gosse, D., Barone, T., \& Kaplan, R. B. (2008). "Breaking silences': Douglas Gosse's story." In Four Arrows \& D. T. Jacobs (Eds.), The authentic dissertation: Alternative ways of knowing, research, and representation (pp. 66-80). New York: Routledge.

Fluck, W. (2003). "Fiction and justice." New Literary History, 34, 19-42.

Goetz. (2001). Women development workers: Implementing rural credit in Bangladesh. New Delhi: Sage.

Goetzman, D. "A brief overview of co-operative inquiry" [Electronic Version]. Retrieved January 22, 2002, from http://npenden.com/An\%200verview.htm

Kabeer, N. (2001). Discussing women's empowerment: Theory and practice Stockholm: Swedish International Development Cooperation Agency.

Kim, H. S. (2007). "The politics of border crossings: Black, postcolonial and transnational feminist perspectives." In S. N. Hesse-Biber (Ed.), Handbook of feminist research. Thousand Oaks, CA: Sage.

McIntyre, M. (2004). "Ethics and aesthetics: The goodness of arts-informed research." In Ardra. L. Cole, Lorri Neilsen, J. G. Knowles \& T. C. Luciani (Eds.), Provoked by art: Theorizing arts-informed research (pp. 251-261). Halifax, NS: Backalong Books/Centre for Arts-Informed Research.

Minh-ha, T. T. (1989). Woman, native, other. Indianapolis: Indiana University Press.

Nagar, R. (2006). "NGOs, global feminisms, and collaborative border crossings." In Sangtin Writers \& R. Nagar (Eds.), Playing with fire: Feminist thought and activism through seven lives in India (pp. 132155). Minneapolis: University of Minnesota Press.

Neilsen, L. (2002). "Learning from the liminal: Fiction as knowledge." Alberta Journal of Educational Research, XLVIII(3), 206-214. 
Kohl 5.1

56 Parpart, J., Connelly, P., \& Barrteau, E. (Eds.). (2000). Theoretical perspectives in gender and development. Ottawa: International Research Development Centre.

Pervaiz, M. (2003). "Impact of state on development of social sciences in Pakistan." Council of Social Sciences Pakistan Newsletter.

Rowlands, J. (1998). "A Word of the times, but what does it mean? Empowerment in the discourse and practice of development." In H. Afshar \& M. Maynard (Eds.), Women and empowerment: Illustrations from third world women. New York: St. Martin's Press.

Rana, S. (2019, February 16). "Govt refuses to register 45 NGOs." The Express Tribune. Retrieved from https://tribune.com.pk/story/1911633/1-govt-refuses-register-42-ngos/

Richardson, L. (2004). "Writing: A method of inquiry." In S. N. Hesse-Biber \& P. Leavy (Eds.), Approaches to qualitative research: $A$ reader on theory and practice. New York: Oxford University Press.

Sayeed, S. (2018, October 4). "Pakistan tells 18 NGOs to leave: Action Aid." Reuters. Retrieved from https://www.reuters.com/article/us-pakistan-ngos/pakistan-tells-18-international-ngos-to-leaveactionaid-idUSKCN1ME1N3

Saigol, R. (2005). "The state of educational discourse in Pakistan." In Inayatullah, R. Saigol \& P. Tahir (Eds.), Social sciences in Pakistan: A profile (pp. 77-127). Islamabad: Council of Social Science Pakistan (COSS).

Sameshima, P. (2008). "Navigating marine drive: Embarking on an arts-informed thesis." In J. G. Knowles, S. Promislow \& A. L. Cole (Eds.), Creating scholartistry: Imagining the arts-informed thesis or dissertation (pp. 151-165). Halifax, NS: Backalong Books.

Sharma, A. (2008). The logics of empowerment: Development, gender, and governance in neoliberal India. Minneapolis: University of Minnesota Press.

Sullivan, A. M. (2009). "On poetic occasion in inquiry: Concreteness, voice, ambiguity, tension, and associative logic." In M. Prendergast, C. Leggo \& P. Sameshima (Eds.), Poetic inquiry: Vibrant voices in the social sciences (pp. 111-126). Boston: Sense Publishers.

Zia, A. S. (2018). Faith and Feminism in Pakistan: Religious agency or secular autonomy. Lahore: Folio. 